\title{
FATHOM
}

\section{The Silencing of the Attempting Pen in Four of Hardy's Works}

Towards a Hardyan Conception of the Writing Artist

Figure de l'écrivain dans quatre textes de Thomas Hardy. Par-delà le silence et au-delà du genre

Nathalie Bantz

\section{OpenEdition}

\section{Journals}

Electronic version

URL: http://journals.openedition.org/fathom/444

DOI: $10.4000 /$ fathom.444

ISSN: 2270-6798

\section{Publisher}

Association française sur les études sur Thomas Hardy

\section{Electronic reference}

Nathalie Bantz, «The Silencing of the Attempting Pen in Four of Hardy's Works », FATHOM [Online],

2 | 2013, Online since 13 September 2013, connection on 20 April 2019. URL : http:// journals.openedition.org/fathom/444 ; DOI : 10.4000/fathom.444 


\title{
The Silencing of the Attempting Pen in Four of Hardy's Works
}

\author{
Towards a Hardyan Conception of the Writing Artist \\ Figure de l'écrivain dans quatre textes de Thomas Hardy. Par-delà le silence et \\ au-delà du genre
}

Nathalie Bantz

1 The primal scene in Hardy's career as a writer is that of silence imposed on his first novel, The Poor Man and the Lady. It was turned down by publishers for various reasons among which, in Meredith's words, that Hardy had "nail[ed] his colour to the mast too definitely in a first book" and produced too "radical [a] satire of society" (Hardy 1984, 62, 63). Yet, the unpublished piece set a precedent. Henceforth, all of Hardy's prose writings had to cope with forced silence. Each time though, novel after story and story after novel, the originally silenced voice, or "attempting pen", to use Anne Finch's phrase ${ }^{1}$, found ways to rise again and again from the ashes. It was eventually put to utter silence, as far as the novels are concerned, after the publication of Jude the Obscure in 1895 (no more novels were written after that date, Hardy being busy throughout 1896 rewriting the original version of The Well-Beloved). The stories continued to be published after that, the last one being written in 1900.

2 Silence is thus a keynote with Hardy, both as the instrument of censorship wielded by critics, publishers and other spokesmen of Victorian propriety, and as the target of Hardy's unrelenting criticism of the codes of Victorian fiction. In some of Hardy's pieces, textualized versions of the silenced writing artist appear, mainly represented by female characters. On the whole, however modern Hardy may seem, he emerges even more subversive in the conception of the writing artist his texts suggest.

\section{It all started with silence}

Silence is both what Hardy had to endure and what he denounced. Under the guise of censorship and emendations demanded by publishers, it maimed his texts even though 
most of the original versions were later restored for volume publications; in the summer 1940 issue of The Southern Review, Katherine Anne Porter notes that " $[. .$.$] his manuscripts$ [were] mutilated for serial publication" (Elliott 17). Hardy's biographer Michael Millgate notes how painful and humiliating the process was for Hardy. Silence was thus the price to pay for publication, but, ironically enough, it was also what Hardy criticized in Victorian society, particularly as regards "the relations of the sexes" (Hardy 1967, 127).

In "Candour in English Fiction", an essay he wrote for The New Review in 1890, Hardy deplores the deceitfulness and dishonesty of Victorian literature (he speaks of "a literature of quackery"; Hardy 1967, 126). Indeed, to him Victorian literature does not "truly [express] the views of life prevalent in its time" (126), it does not "reflect and reveal life" (128) or criticize life. Therefore, the Victorian writing artist refrains from letting the characters "act as they will" lest "the thunders of respectability" should be brought "upon his head", lest he should "ruin his editor, his publisher and himself" (130). To Hardy, Victorian fiction lacks sincerity. It veils, or to put it differently, it silences, "things which everybody is thinking but nobody is saying" (133). Here is what William Locker, the son and assistant of The Graphic's editor, writes to Hardy after receiving the manuscript of A Group of Noble Dames for the Christmas 1890 issue:

[...] I cannot think that [the fathers, who are accustomed to read or have read in their family circles stories in the Graphic] would approve for this purpose a series of tales almost every one of which turns upon questions of childbirth, and those relations between the sexes over which conventionality is accustomed (wisely or unwisely) to draw a veil. (Gatrell 81)

In other words, Victorian propriety, that is "English prudery" (Hardy 1967, 132), has pronounced a few topics unfit for an all-public readership, and expects writers to follow suit, that is, to apply to themselves a strict rule of silence as regards those topics. In such a context, the "faithful artist [...] [belies] his literary conscience" (129-130) and, because he cannot speak frankly, is all but a hushed voice.

On less general considerations and on a more personal basis, Thomas Hardy also had to face the class-minded judgment of reviewers who would certainly rather have silenced him, and who wished he did not "make experiments in a form of language which he did not seem clearly to understand, and in a style for which he was assuredly not born". These are Mowbray Morris's words ${ }^{2}$. They illustrate the condescension towards artists from humble background:

[Hardy] is too apt to affect a certain preciosity of phrase which has a somewhat incongruous effect in a tale of rustic life; he is too fond - and the practice has been growing on him through all his later books - of writing like a man 'who has been at a great feast of languages and stole the scraps', or, in plain English, of making experiments in a form of language which he does not seem clearly to understand, and in a style for which he was assuredly not born. It is a pity, for Mr Hardy had a very good style of his own once, and one moreover excellently suited to the subjects he knew and was then content to deal with. (quoted in Green 535)

Hardy's fiction was thus tolerated provided he did not overstep class barriers, which is nevertheless what he did. His main characters do likewise, as they tend to speak like the educated narrator.

8 Thus, both as a writer bent on producing an honest portrayal of life (the faithful writer evoked earlier) and as a writer addressing a class he did not belong to, Hardy was unsettling. The end of his career as a novelist can therefore be interpreted as the victory of the silencing power of his detractors. Yet the poet's voice went on. 


\section{Women writers as silenced voices}

9

$$
\begin{aligned}
& \text { fiction. Quite interestingly, all but one are female characters, as though women, and more } \\
& \text { specifically women as writers, were to Hardy the best fitted figures to incarnate the } \\
& \text { silenced writing artist he sees himself to be, and this on two counts. First, a parallel can } \\
& \text { be drawn between Hardy and women. Rosemarie Morgan explains that the "frustration" } \\
& \text { and "humiliation" caused by "perpetual censure and unremitting condescension on the } \\
& \text { part of the critics" made him sympathetic to the plight of women, especially poor ones } \\
& \text { (Morgan xv-xvi). In other words, his struggle to gain recognition as an artist from the } \\
& \text { lower classes, and women's attempt to earn recognition as human beings entitled to the } \\
& \text { same rights as men, can both be expressed in terms of unheard voices: } \\
& \text { Indeed, his intense feelings of isolation, his deep sense of alienation from the } \\
& \text { Victorian middle-class world he had entered as a popular, if controversial, novelist, } \\
& \text { must have urged him to a close understanding of the condition of women, in so far } \\
& \text { as he and they felt, sorely, the effect of society's institutionalized values; in so far as } \\
& \text { each had to struggle to be heard, to gain recognition; in so far as oppression by } \\
& \text { either class or sexual division was the experience of both. (Morgan xv) }
\end{aligned}
$$

Unsurprisingly, there are a few representatives of the writing artist in Hardy's prose

, women and the writing artist (the faithful writer Hardy is bent on being) both have to compromise with, and endure, the pressure of convention, prudery and propriety. More precisely, the writer is expected to keep silent on some specific topics (censorship is forced silence), and he or she violates conventions if the rule is not respected. As for woman, she ought to be silent on what does not pertain to her domestic sphere. As a writer she goes against the patriarchal codes of society. The figure of the woman writer thus epitomizes figures likely to be silenced, and promised to such fate because they defy conventions and question the place allotted to them by society ${ }^{3}$. It is the case of Hardy both as a writer of modest origins and also as a "faithful artist".

11 The woman writer is transgressive, as Anne Finch's poems tell us. Although they date back to the late seventeenth and early eighteenth centuries, they are still relevant in Hardy's time:

Alas! A woman that attempts the pen

Such an intruder on the rights of men,

Such a presumptuous Creature is esteem'd

The fault can by no virtue be redeem'd.

(quoted in Gilbert \& Gubar 3)

In The Madwoman in the Attic by Sandra Gilbert and Susan Gubar, and elsewhere, the pen is explained to be a metaphorical penis, reserved to men only. Therefore, the woman who attempts the pen is active, whereas by definition she ought to be passive and celebrate the talents of her husband or of the men around her. Through her writing she acts for herself, she ceases to exist only as a purveyor of happiness for her family and she stands as a rival to man, as in her own turn she can create her own story for herself. The only possible outcome for this transgressive woman is silence, as though silence were the rightful retribution awaiting women who overstep the limits supposedly assigned by their feminine nature. It comes as no surprise, then, that for the Victorians the only acceptable figure for woman is Coventry Patmore's "Angel in the House", a submissive meek and silent figure. In such a system of norms and beliefs, the only good writer is a censored, that is, a silenced, writer. 

Ethelberta (The Hand of Ethelberta, 1875), Lizzy ("The Distracted Preacher", 1880) and Ella ("An Imaginative Woman", 1894), exemplifies, on a smaller scale, that of the writing artist generally speaking.

14 of her attempts at the pen is a personal success. To start with, she writes her father's sermons. In other words, her father somehow muffles her voice and steals her words. What she writes is dictated by "the father", "the father" here being also meant as the representative of the law. Besides, she is never encouraged by her family to achieve intellectual independence, through writing for instance. Furthermore, she keeps her writing activity secret, as if it were something improper for her, as a woman, to do. Once the secret is revealed, she receives no support from her father: he predicts that no publisher will accept the book. If she is advised by her stepmother to go ahead and publish it anyway, it is certainly not for the right reason, one might say. Her argument is not that it might bring Elfride intellectual satisfaction or even financial independence, but that it will secure her future husband's respect: woman's only horizon is marriage, and everything has to be done to that end. When her romance eventually comes out, under a male pseudonym of course, it attracts the sarcastic comment of its only reviewer.

What Hardy seems to criticize here is that the budding womanhood Elfride represents is maintained in a state of perpetual infancy. Here is what her stepmother says: "Her father and I have to command her and keep her in order, as you would a child" (Hardy 1998, 173). Accordingly, her prose lacks the maturity Elfride would have acquired had she benefited from the education that her intellectual curiosity naturally deserved. But, as a woman, she is somehow trained to produce the childish prose her reviewer laughs at. Everyone around her, men and women alike, actively participate in perpetuating a system which breeds immature women, and, consequently, poor women writers. Elfride dies, and a permanent and actual lid of silence is put on her voice. One is entitled to suspect that, had she lived, such a lid would nevertheless have covered it.

Ethelberta, for her part, is a recognized and successful poetess whose identity as the daughter of a butler is first kept secret, and whose father is believed to be the late Bishop of Silchester. At first glance she might seem to give the lie to Elfride's example but after a closer look, she does not fare any better than the other heroine. She is only able to indulge her passion for writing poetry as long as she does not have to earn her living. Once her mother-in-law, whom she was living with as a young widow, disinherits her before dying, she has to put an end to her writing. She decides to turn to public storytelling, and in a way becomes a public woman in the sense that, no longer protected by her status as a wealthy young widow, she is commodified and ready to be traded on the marriage market. Inspiration deserts her and she can no longer write, neither prose nor verse. She is then selected, like some precious thing, by a wealthy old widower who manages to marry her. Writing is no longer evoked, neither during the period of the man's courtship nor afterwards.

17

exta's example furthers the conclusions reached with Elfride's. Dealing with literature seems to be an activity reserved to the leisured elite. Those who must earn their living have other fish to fry, to put it colloquially, and those who wish to live by their pen may find the confrontation with reviewers difficult, as Elfride's, but also Hardy's, experiences show. Poor people, and poor women in particular, are not welcome in the private circle of literature makers, Hardy seems to say, probably with his own case 
in mind. Ironically enough Ethelberta, unlike Elfride, does not die but gets married, two statuses Hardy may have tightly, albeit unconsciously, connected. Thus another voice, Ethelberta's, is silenced, first because she loses her status as a rich widow and becomes poor again, secondly because she becomes a married woman.

Ella's case, in "An Imaginative Woman", completes the idea that the married woman should be unavailable for the act of writing and had better remain silent. Ella could be interpreted as a version of Ethelberta after a few years of marriage (although Ethelberta's aged husband does not father any child). She is bored with her humdrum life with a man she has nothing in common with, and her daydreaming leads her to poetry writing. Contrary to Elfride and Ethelberta, she starts writing after getting married, which is probably doubly unacceptable for the Victorians: she gets so involved in her activity that she neglects her family, the capital crime a woman, programmed to become an Angel in the House, can commit. Her passion for a young poet, Robert Trewe, has more to do with her fascination for his talent than with real infatuation. It is not so much the man she wants to touch (in a scene replete with sexual allusions, she kisses his portrait in bed), it is her own impregnation by such a talented creator she dreams of. Hence the passage when she tries on his raincoat and puts on his hat: "His heart had beat inside that coat, and his brain had worked under that hat at levels of thoughts she would never reach" (Hardy 1988, 386; author's italics). Death is the punishment that awaits such a woman, whose crime, again, is not so much that she has adulterous fancies, but that she wishes to fulfill a most personal and intimate ambition, that of being a creator of something else than children: "Ella was more than a multiplier of her kind" (383), says the narrator. So a woman, and more precisely the woman writer, who tries to escape her fate as a wife and a mother, must be punished.

As for Lizzy, the woman smuggler of "The Distracted Preacher": she will not have to pay as dearly for her transgressive behaviour in so far as she will not die. In the official version of the text, which is of course not the one Hardy favoured, she ends up marrying preacher Stockdale, a symbolic renunciation of whatever she did and whoever she was before Stockdale tried to change her. In a way she marries the law, the law she has always so courageously defied. Accordingly, she loses her own personal voice and henceforth is only allowed to use her husband's instead. Even though she may attempt the pen, whatever she writes is systematically overseen by Stockdale, and strongly jars with her former personality: he "got [her text] printed, after making some corrections, and putting in a few powerful sentences of his own" (Hardy 1988, 203). Nothing is left of the fiery woman ready to sacrifice her love to her cause. She has lost her voice.

Provided the woman writer does not question the values and assumptions of Victorian society, she may practice her activity untroubled. Thus Lizzy becomes a mouthpiece for Victorian society, Elfride only produces immature and therefore unthreatening texts, and Ethelberta puts an end to her attempts at poetry, judged by two ladies to be too sensuous, if not sensual. As for Ella, her education as a Bovarian bourgeoise prevents her from writing good poetry. Had she been able to aesthetically vent her pent-up fancies, she then might possibly have been a good woman writer (by Hardy's standards), and thus a censored one. Her fault finally does not even lie in what she writes, because she is harmless as a writer, but in the fact that she neglects her household.

Woman has to be as silent as the Angel in the House, that is, if she happens to write, she must be inoffensive and benign. Otherwise she must be put to eternal silence, which amounts to the same in the end, and which Virginia Woolf refused. To her, "killing the 
Angel in the House was part of the occupation of a woman writer" (Woolf 236). Woolf's angel is not the real woman whose voice must make itself heard, but the meek, passive and childish woman whose gender ${ }^{4}$ is defined, and whose mind is shaped, by the strictures of Victorian society.

\section{The writing artist as an ungendered voice}

Robert Trewe, the poet from "An Imaginative Woman", is the only man writer in Hardy's works. He shows that the plight of women writers extends to men alike. In other words, men writers hardly fare any better than women writers. In fact, Trewe's poetry does not comply with the canon of the day and might very well be the sort of poet to be frowned upon by "right-minded" reviewers and critics, as the narrator ironically calls them: his rhymes have a tendency to be loose, his verse is both "impassioned" and "luxuriant". He dies because he is too lonely to endure the harshness of his reviewers, and also probably because he does not fit into the ready-made identity Victorian society has in store for men and for writers. He is a disruptive element in what must be a smooth order of things, and therefore he must die.

Interestingly enough, Trewe seems to be a masculine version of Ella, and vice versa. $\mathrm{He}$ writes what she is unable but would love to compose, he is depressed, highly sensitive (two characteristics usually describing women) and he is often inspired by the same subjects as she is. On a larger scale, a closer look at Elfride, Ethelberta and Lizzy reveals that all three women display traits and attitudes usually reserved to men.

Elfride is thus said to ride alone contrary to what is expected from a well-behaved young woman; she defies all decorum when she, not unlike a man, uses her chemise as a rope to save Henry Knight from a fatal fall; later, the text evokes the chess game she lets Steven Smith win': she then is in the position of the lover who does his mistress a favour.

In two thirds of The Hand of Ethelberta, the eponymous character is described in such a way that she heavily contrasts with her sister Picotee, the embodiment of the childish and naïve woman Hardy complains Victorian fiction produces. "[W]hat an absurd child you are", Ethelberta tells her (Hardy 1997, 55). By contrast, here is how Ethelberta's mother-in-law upbraids her: "What a tomboy you are!" (22). Described as a "simple heart" (286), her mother is an older version of her sister Picotee. The one person Ethelberta seems to be close to is her father, who like her is the family breadwinner. They constantly exchange letters, and he obviously reads all her poems. He sees her not as a woman to be re-married but as a person whose happiness is at stake: "Never you mind us, mind yourself", he tells her (285). Some kind of maleness in Ethelberta is also suggested when the narrator compares the young woman not to a jewel or a princess, but to a brilliant book. As she herself writes books, one might be invited to think that she creates herself the way she creates books, an opportunity denied to women who are expected to simply reproduce the models they have been taught. It is also suggested that, contrary to standard usage that has women being muses for men writers, Ethelberta uses Christopher as subject matter for her poetry: "[...] thinking me no longer useful as a practical chance, she [has made] me ornamental as a poetical regret" (75-76). Yet Hardy could not go on with such an inverted character, and he had to introduce fairy-tale elements to give his story the happy, if artificial, turn his reviewers and readers were expecting. This explains why Ethelberta stops writing and devotes herself to finding a husband. This also accounts 
for the fairy-tale ending where the heroine inherits a great domain and ends up on fairly good terms with her senior husband.

As for Lizzy, she is immediately described as a smuggler who, on occasion, puts on her dead husband's clothes to hide her identity. Such an inversion, undoubtedly frowned upon by the Victorians, is punished at the end when Lizzy's voice in her book is so to speak silenced by her husband's.

Finally, Ella's daydreams are all about a male version of herself she desperately seeks but that remains aloof. Trewe has the same longings for a companion of the opposite sex: "Perhaps had I been blessed with a mother, or a sister or a female friend of another sort tenderly devoted to me, I might have thought it worth while to continue my present existence" (Hardy 1988, 396).

By uniting the two genders into one character with Elfride, Ethelberta and Lizzy, and by having Ella's and Trewe's quests for a counterpart of the opposite sex fail, Hardy seems to be demonstrating how tragic and irrelevant it is to dissociate the feminine and the masculine. Here is probably where he is most modern. Not only does he prove his liberal ideas as regards women, their education and the plight of women writers. Not only does he defend his view of literature. Through his five characters, he also moves the debate on the writing artist further and on then untrodden paths. To him obviously, the writing artist is both male and female or rather, whether a writer is a man or a woman is irrelevant. What he seems to be insisting upon is not whether the artist is a man or a woman, but the freedom and maturity with which this artist must write if truth is what the writing aims at. He anticipates what Barthes calls "the Neutral", that is, the term which is not included in the paradigm. The paradigm implies that a writer is either male or female, and this is all the truer and all the more fiercely insisted upon in Victorian times when the boundaries between genders had to be strongly reaffirmed for fear of degeneracy. Hardy, for his part, deconstructs gender lines, and the paradigm. His view seems similar to that of George Sand, when she wrote to Flaubert about general matters and writers in particular:

Il n'y a qu'un sexe. Un homme et une femme c'est si bien la même chose que l'on ne comprend guère les tas de distinctions et de raisonnements subtils dont se sont nourries les sociétés sur ce chapitre-là. (quoted in Fabre $\$ 34)^{6}$

In the same way, he anticipates what a feminist like Monique Wittig says about the neutrality of the writer:

Il n'y a pas de littérature féminine pour moi, ça n'existe pas. En littérature, je ne sépare pas les femmes des hommes. On est écrivain, ou pas. On est dans un espace mental où le sexe n'est pas déterminant. Il faut bien qu'on ait un espace de liberté. Le langage le permet. Il s'agit de construire une idée du neutre qui échapperait au sexuel. ${ }^{7}$

Similarly, what matters for Hardy is what a writer is, that is, what it means to be a writer and what a writer should write about, regardless of gender.

It eventually seems that Hardy goes even further than George Sand and Monique Wittig, however misogynistic and conservative he may have been labelled here and there. Indeed, if Sand and Wittig mainly speak in favour of women and women's rights, Hardy has a more universal view. He does not only struggle for his own right to make himself 
heard, as a writer from the lower classes; he does not only plead for women's rights and education. More generally, he is a spokesman for the writing artist, the figure itself representing all the silenced voices that must "unlearn to not speak" (Gilbert \& Gubar $83^{8}$ ). On the whole, he could better be defined as a universalist, universalism being opposed to differentialism and essentialism. Through his five writing figures, Hardy proves that in matters of literary creation at least, gender is not the point. What matters is that the speaking voice goes on, unsilenced.

\section{BIBLIOGRAPHY}

Elliott, Ralph W., Thomas Hardy's English, Oxford: Basil Blackwell, 1984.

Fabre, Daniel, «L'androgyne fécond ou les quatre conversions de l'écrivain », Clio. Histoire,

femmes et sociétés [En ligne], 11 | 2000, mis en ligne le 24 mai 2006, consulté le 12 septembre 2013. URL : http://clio.revues.org/214; DOI : 10.4000/clio.214

Gatrell, Simon, Hardy the Creator: A Textual Biography, Oxford: Clarendon Press, 1988.

Gilbert, Sandra M. \& Susan Gubar, The Madwoman in the Attic, New Haven \& London: Yale University Press, 1984.

Green, Laura, “'Strange [In]difference of Sex': Thomas Hardy, the Victorian Man of Letters, and the Temptation of Androgyny", Victorian Studies 38:4 (Summer 1995): 523-549.

Hardy, Thomas, The Hand of Ethelberta (1876), London: Penguin Classics, 1997.

Hardy, Thomas, A Pair of Blue Eyes (1872-1873), London: Penguin Classic, 1998.

Hardy, Thomas, “Candour in English Fiction” (1890), in Thomas Hardy's Personal Writings, ed. Harold Orel, London: Macmillan, 1967, 125-133.

Hardy, Thomas, The Life and Work of Thomas Hardy, by Thomas Hardy, ed. Michael Millgate, London : Macmillan, 1984.

Hardy, Thomas, Collected Short Stories, London: Macmillan, The New Wessex Edition, 1988.

Higonnet, Margaret (ed.), The Sense of Sex: Feminist Perspectives on Thomas Hardy, Urbana: University of Illinois Press, 1993.

Morgan, Rosemarie, Women and Sexuality in the Novels of Thomas Hardy, London and New York: Routledge, 1988.

Woolf, Virginia, "Professions for Women", The Death of the Moth and Other Stories, San Diego, New York, London: Harvest Books, 1942.

\section{NOTES}

1. Anne Finch (1661-1720). She was the Countess of Winchilsea, one of the first women British poets to be published.

2. Chief editor for Macmillan's Magazine from 1885 to 1907. 
3. On Hardy's "muted" heroines, especially Tess, see Margaret Higonnet, “A Woman's Story: Tess and the Problem of Voice" (Higonnet 14-31).

4. Sex is here considered as pertaining to what is anatomical, physiological and biological, and gender as referring to everything else.

5. The scene should of course be read against the other chess-game scene, in which Elfride is dominated by Knight. See Mary Rimmer, "Club Laws: Chess and the Construction of Gender in A Pair of Blue Eyes" (Higonnet 203-220).

6. "There is only one gender. Men and women are so much the same thing that one cannot understand why there has always been so much discussing on that chapter" (my translation).

7. Monique Wittig interviewed by Claire Devarrieux, Libération, 17 June 1999. "To me there is no such thing as women's literature. I do not differentiate between men writers and women writers. You are a writer or you are not. You are in a mental space where sex does not matter. It is important to have some space where you are free. Language is such space. It is necessary to imagine some neutral identity that would be un-sexual or rather, un-gendered" (my translation).

8. Gilbert and Gubar paraphrase a poem by Marge Piercy entitled "Unlearning to not Speak".

\section{ABSTRACTS}

Silence represents for Hardy the primordial scene. It is inflicted on his first novel The Poor Man and the Lady which was rejected on account of its so-called "radical satire of society" (Meredith). From then on, silence will take the form of censorship and will compel Hardy to "mutilate" his texts. On the other hand, silence, that is the prudery and hypocrisy of Victorian society as applied to authors and their fiction, is also what Hardy relentlessly denounces. His vision of the writing artist who "expresses truly the views of life prevalent" in a given time is at cross purposes with that of publishers and the reading public for whom the only good writer keeps silent on a few unwelcome topics. Quite interestingly, all but one of the few writing artists in Hardy's fiction are women, as if women were the best possible figures to exemplify the plight of the silenced writer in a puritan society. Even worthier of consideration is the fact that these four women artists share masculine attributes whereas the only man writer has conspicuous feminine characteristics. It seems that beyond his understanding of women's struggle to be heard in an oppressively patriarchal society and his sense of the parallel attempt of the writing artist to prevent the silencing of his or her voice by the same constraining powers, Hardy is voicing his own personal view of the writing artist as an ungendered figure: what matters is not the artist's gender but the speaking voice. In this regard, Hardy anticipates universalist thinkers of modern times and actively participates in the contemporary debate opposing differentialists to universalists. His modern and subversive vision of literature and the writing artist has travelled through time to us, and this is where his victory against the forces of silence is.

La mise au silence représente chez Hardy une scène primordiale sinon la scène primordiale. C'est la punition infligée au premier roman The Poor Man and the Lady en raison de sa nature jugée trop radicalement satirique : il ne sera jamais publié. C'est ensuite la censure imposée par les éditeurs qui exigent réécriture, altérations, autant de modifications des textes vécues par Hardy comme des mutilations. Il faut au contraire libérer la parole de l'écrivain que font taire la pudibonderie et l'hypocrisie de l'ère victorienne, car écrire, dit Hardy, c'est choisir d'être l'observateur et l'analyste de son temps sans restriction des sujets. Dans son œuvre Hardy met en scène des 
personnages écrivains. Ce sont pour la majorité des femmes. Est-ce à dire que Hardy voyait la femme, corsetée par la norme, comme plus à même d'incarner la figure de l'écrivain contraint par les conventions? Il apparaît également que ces femmes présentent des caractéristiques traditionnellement réservées au masculin et qu'inversement, l'unique personnage-écrivain masculin partage de nombreux traits avec le sexe dit « opposé ». Les guillemets marquent bien la suspicion dans laquelle Hardy semble tenir la distinction imposée entre les deux genres, de façon générale et plus encore lorsqu'il est question d'écriture. Son regard de sociologue ne s'y est pas trompé : pour lui l'écriture procède non pas d'un genre mais d'une expérience. Anticipant les universalistes, il conçoit l'écriture comme une voix libre au-delà du genre et vient par là nourrir un débat toujours en cours. Il ancre dans le même temps sa pensée dans la modernité.

INDEX

Mots-clés: roman, silence, censure, écriture, éducation, genre, Neutre (le), transgression

Keywords: novel, silence, censorship, writing, education, gender, Neutral (the), transgression oeuvrecitee Poor Man and the Lady (The), Pair of Blue Eyes (A), Candour in English Fiction, Group of Noble Dames (A), Hand of Ethelberta (The), Distracted Preacher (The), Imaginative Woman (An)

\section{AUTHOR}

NATHALIE BANTZ

Université de Nancy 2 